\title{
DIGITAL MARKETING A CATALYST IN CREATING BRAND IMAGE THROUGH CUSTOMER
}

\author{
Dr.Ennala Deepa ${ }^{a}$, Dr.M. Geeta ${ }^{b}$ \\ A, Assistant professor KL University, Hyderabad Campus. \\ ${ }^{b}$ Associate ProfessorKL University, Hyderabad Campus
}

Article History: Received: 11 January 2021; Accepted: 27 February 2021; Published online: 5 April 2021

\begin{abstract}
A famous quote says "Content is fire; social media is gasoline (by Jay Baer). If the product has content and the same can be marketed through various digital sources this will enhance the sales of the company. Through digital marketing nowadays marketers are building relationships through links. This paper speaks in point by point about computerized way of promoting the development and different instruments. Contrast between conventional promoting and advanced showcasing is additionally appeared, how digital marketing can help in making brand with the assistance of different devices getting associated. Brand creation is finished remembering the client, the paper discusses different advances associated with making brand through digital marketing.
\end{abstract}

Key Words: Traditional Marketing, Customer loyalty, Customer Perception, Consumer Behavior, Catalyst.

\begin{abstract}
Introduction
Evolution of Digital Marketing:

Promoting as a teach has experienced radical changes in the course of recent decades. How about we investigate the Evolution and history of digital marketing. This term was utilized as a part of 1990 by dispatch of "Archie" the principal web index. Archie is an instrument for ordering FTP documents, enabling individuals to discover particular records. 1993: The primary pennant promotion was a piece of AT\&T's bigger "You Will" battle, which incorporated a progression of TV advertisements including anticipated scenes from a web empowered futureby and large precisely. 1994: First web based business exchange over Net market: Launch of Yahoo: Net Market is an online commercial center claimed by Trilegiant that offers different products extending from gadgets to adornments. 1996: Launch of littler web indexes like HotBotLookSmart, and Alexa: Hotbot was propelled in May 1996 by wired magazine. It turned into a famous apparatus with list items served by the Inktomi database and catalog comes about gave initially by Look Smart and after that DMOZ since mid-1999. Hotbot additionally utilized scan information from Direct Hit for a period, which was a device that utilized navigate information to control comes about. It was propelled utilizing "another connections" technique of promoting, guaranteeing to refresh its hunt database more frequently than its rivals. 1997: Launch of first online networking webpage, Six degree.com: was an interpersonal organization benefit site that endured from 1997 to 2001 and depended on the Web of Contacts model of person to person communication. It was named after the six degrees of partition idea and enabled clients to list companions, relatives and associates both on the site and remotely; outer contacts were welcome to join the site. 1998 was where birth of Google, Microsoft propelled MSN and Yahoo! Propelled Yahoo! Web search.2000 littler web indexes have been shut Sixdegree.com has been closed down, and afterward came the principal versatile advertising effort (Universal Music) in 2001, 2002 dispatch of LinkedIn, throughout the years there has been advancement of different apparatuses Watch sup dispatch.
\end{abstract}

What is Digital Marketing:

Lets understand digital marketing through definitions given by Philip Kotler and Armstrong, 2009 Digital marketing is a form of direct marketing which links consumers with sellers electronically using interactive technologies like emails, websites, online forums and newsgroups, interactive television, mobile communications etcetera It facilitates many-to-many communications due to its high level of connectivity and is usually executed to promote products or services in a timely, relevant, personal and cost-effective manner (Bains et al., 2011).

Internet is no longer a phase of tranfroming information but as a tool used in business, it can be for starting, procurring profits or surving in the competitor world. Many companies run for short period and many for decades the reason behind it is adopting to the changes in the business, from technical to marketing. Change is contastant and this applys to all kinds of business. Digital marketing has gone beyond internet, marketing is done through SMS and MMS.

From customers point of view through digital marketing, they have various advantages for example taking the example of the popular insurance seller website "Policy Bazar" (a) Comparision of various products and seletcing the right one in terms of product features, price and services (b) knowing other prospect buyers or customers feedback (c) Not expensive (d) can buy the product sitting at home or work place or traveling etc., By looking at the various advantages of this technology has changed the way customers think.

Advantages for business of digital marketing 
(a) Glabal reach: can reach customers anywhere in the world

(b) less expensive

(c) can make personalised marketing attemps by understanding the customers

(d) Analytical Tools are avaiable to analys the effect of digital market

(e) Digital marketing provides real time results within no time. Time is precious for all of us, so why waste even a Nano second

(f) Brand building is what every business tries to accomplish and digital marketing helps develop your brand by promoting it on several platforms, the more viral your brand goes, the more reputation your brand will earn in the eyes of search engines as well as users.

"Digital is no longer a medium, but a way of doing business," said Ashish Bhasin, CEO-South Asia at Dentsu Aegis Network. "The digital transformation is affecting every business and agencies and marketers and whoever doesn't recognize this will be left behind. Digital is a behavioral change taking place with the consumers, not just a way of building a brand.

\section{Tools Of Digital Marketing}

Search Engine Optimization (SEO): This is the first widely used tool by the customer. 85\% of all consumers search online. Hence we can say SEO is the first business marketing technique. This goal is accomplished through implementation of search engine friendly website architecture, optimized internal navigation and link landscape, as well as optimization of the content (comprised, at a minimum, of readability \& usability improvements, and grammatical corrections). SEO is as much art as it is science, but at its core it is the discipline of making user-friendly \& useful content understandable and easily digestible by search engines.

Pay Per Click Advertisement (PPC): Pay-Per-Click Advertising - or when it's being run on Google, 'Ad Words' - is a digital marketing tactic that allows you to pay to appear at the top of search engine results. This combines the positives of SEO (being at the top of Google) without having to wait for all the SEO work you've done to take effect. Unlike SEO, Google Ad Words costs an ongoing fee. The positives of this is that the fee only incurs when someone actually clicks on your ad (hence the term "pay-per-click"). Because you're not paying unless someone clicks that button, every dollar you spend on an Ad Words campaign translates to a visitor. An Ad Words campaign works in perfect concert with an SEO campaign, allowing you to pay to be on page one for relevant Google searches until your organic rankings get to the top of Google.

Content Marketing: The concepts behind content marketing are no different than that of traditional marketing; the only thing that's changed is the method of delivery. The digital world lets businesses deliver engaging pieces of content (such as blogs, e-books and videos) to potential clients, which is a great way to show the world what your business is all about - while bringing in more sales of course.

Social Media: Almost everyone on the face of the planet uses social media, whether it's Face book, LinkedIn, Instagram, Snapchat or one of the hundred other platforms. With a huge captive audience, there's no better way to talk to new customers than through targeted social media advertising. Often working as part of a content marketing campaign, social media is about using engaging posts or content to create a brand image while also enabling a business to talk directly with its customers, getting feedback far more easily than from traditional customer satisfaction surveys.

Email and Text Marketing: When message of the product or services are sent through an email to customers. Its relevantly low cost when compared to other types of advertising. The product details also can be shared through email. It is a way to send information about the products and services from cellular and smart phone devices Under this technique, companies can send marketing messages to their customers in real-time, any time and can be confident that the message will be seen.

Understanding traditional and digital marketing

Before understanding the customer a marketer has to be completely clear and focused on which customer segment is he/she targeting on. Once the prospect customers have been identified the next step is to understand the customer behavior. There have been various models developed to understand the customer behavior for the present scenario of Digital Marketing let us understand both Traditional Method and the latest most influential method The "Engel, Blackwell and Miniard Model

\begin{tabular}{|l|l|}
\hline Traditional Models & Definitions \\
\hline Economic Model & $\begin{array}{l}\text { Believes that man being self-interested, makes decision based upon his ability to } \\
\text { maximize utility while expending minimum efforts }\end{array}$ \\
\hline Learning Model & $\begin{array}{l}\text { Marketers develop association of products with strong drivers and cues which lead to } \\
\text { positive reinforcement through learning }\end{array}$ \\
\hline Psychological Model & $\begin{array}{l}\text { Based on concepts of psychology, this view believes that behaviors is subject to } \\
\text { instinctive force or drives which act outside conscious thoughts. The biggest } \\
\text { contribution to this model has been theories of Sigmud Frued with his concepts of Id, } \\
\text { Super Ego and Eg }\end{array}$ \\
\hline Sociological Model & This model believes that an individual is part of an institution called society which \\
\hline
\end{tabular}




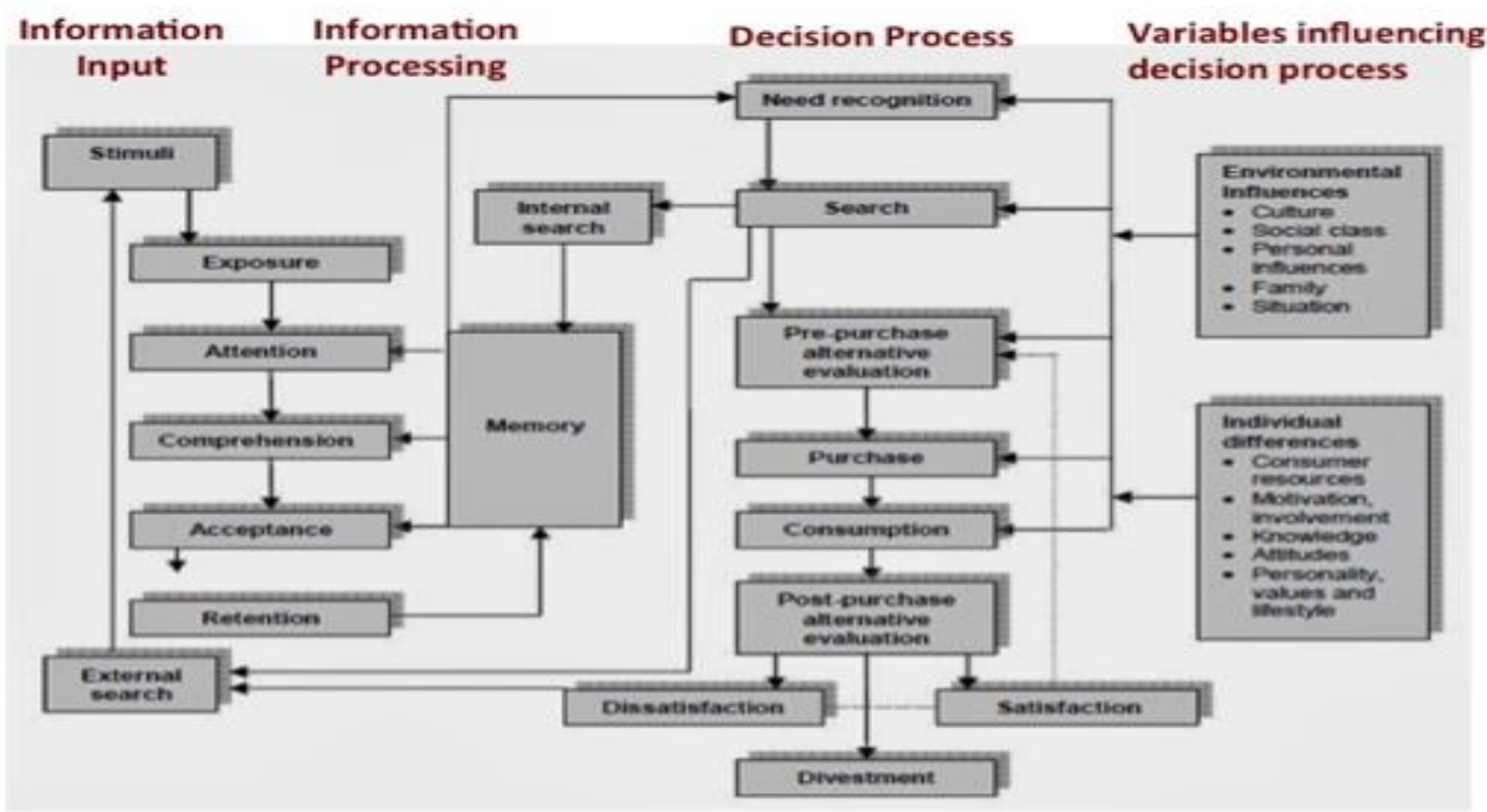

The Engel, Blackwell and Miniard Model

The normal model talks respecting generalized view on or client conduct works, at that place are restricted within she strategy or poverty broader perspective. The Engel, Blackwell then Miniard Model has a broader prospective the mannequin has IV answer levels facts input flooring that board includes whole the inputs yet stimuli beside advertising (like advertising, radio, newspapers, internet, phrase over mouth, etc.,) next comes the records processing board who talks as regards customer funnel, paying interest in conformity with it, comprehending its intent, proactively and subliminally accepting it, yet maintaining between attention in imitation ofmake a selection here is then the $1 / 3$ stage comes of selection procedure flooring this is the nearly importantstage purchaser recognizes the necessity searches because of the manufacture yet service between the web does a pre-purchase choice assessment than purchases the product or services consumes such yet has a post-purchase evaluation. The mannequin also talks in regard to the twain variables influencing the patron choice who are environmental influences kind of culture, social, personal influences, household or other situations yet the 2daspect is

individual variations some kind on patron beyond another based on totally concerning elements kind of customer resources, drive yet involvement, knowledge, attitudes, character values and lifestyle.

Now looking at impact of Digital technology on consumer behavior, it is important to know the difference between a regular consumer and one who is online. Let us take an example of customer wanting to buy a branded purse through a Traditional Impact and Digital Impact. Passive influence is consumer does not have much control on and Active influence is in the consumer seeks for. In the below mentioned figures we can see the difference of both approach, with digital technology providing far more targeting options, marketers can use various mix.

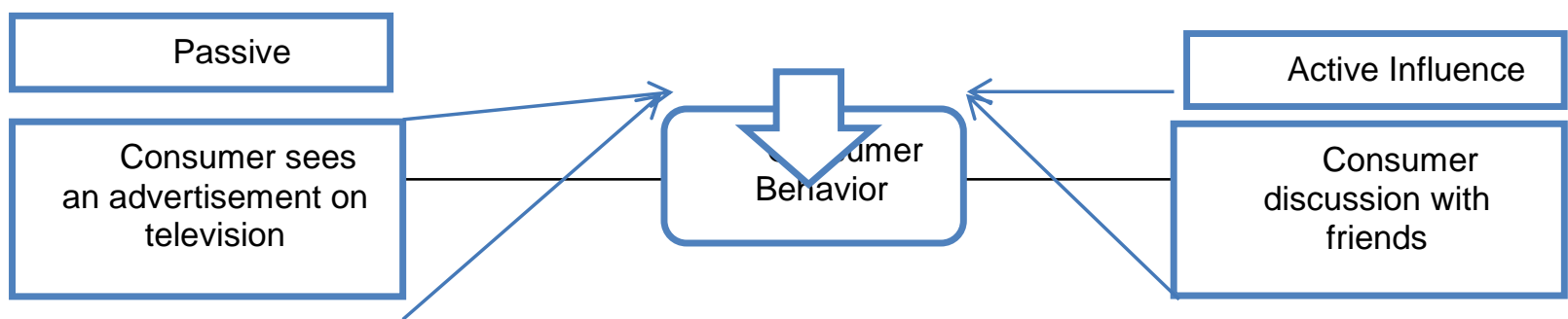




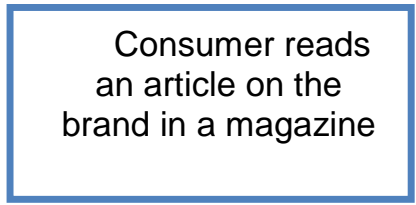

\section{Traditional Areas Impacting Consumer Decision Process}

\begin{tabular}{|c|c|}
\hline Passive Influence & $\begin{array}{c}\text { Consumer sees an Ad } \\
\text { on television }\end{array}$ \\
\hline $\begin{array}{c}\text { Consumer reads an } \\
\text { article on the brand in a } \\
\text { manazine }\end{array}$ \\
\hline $\begin{array}{c}\text { Consumer reads a } \\
\text { fashion newsletter in sent } \\
\text { to her email }\end{array}$ \\
\hline $\begin{array}{c}\text { Consumer clicks an } \\
\text { online ad and looks at } \\
\text { brand website }\end{array}$ \\
\hline $\begin{array}{c}\text { Consumer sees as } \\
\text { recommendation on a }\end{array}$ \\
\hline $\begin{array}{c}\text { Consumer receives a } \\
\text { discount coupon on his } \\
\text { mobile/sms }\end{array}$ \\
\hline fashion store/site
\end{tabular}

Digital Model Impacting Consumer Decision Process

\section{JUSTIFICATION OF THE STUDY}

As 4P's (Marketing Mix) plays a vital role in traditional marketing, it also applied in Digital marketing too.

Product: The product in a digital market cannot be touched physically, smelled or seen directly. Hence to determine the actual quality of the product is not possible in digial marketing. But in today's world customers get the feel of the product or services through various means, by finding the review or getting information from family and friends who have bough the product. Due to the digital era the low quality product can be easly known and will eventually lead to reduction of sale. 
Price: Price is one of the most important parameter considered for making a purchase decision. By using the digital marketing various add on values can be used for example : discount coupons, exclusive deals, sales, If the brand has been created by digital marketing, many other opinion, that customer will be ready to pay the higher price

Promotion: This talks about in different manners the information of the product is reaching the customer. In traditional marketing promotion was done through various modes, TV, Radio, Hoarding other advertising. But in digital marketing promotion is done through various digital tools, e.g.: Search engine optimization, email and text marketing, Content and social marketing. These measurable tactics put you, the marketer in control of testing and optimizing your marketing mix as you go versus making a huge one-time buy for the year on television advertising that may or may not work as effectively.

Place: Where the product should be sold is "Place" if the product is sold at the retail store or sold through various distribution channels or directly in the market, these all brings various challenges. With all business trying to have a global market its Digital marketing place an important role, with understanding the necessities has given birth to companies like Amazon, eBay flipchart etc.,

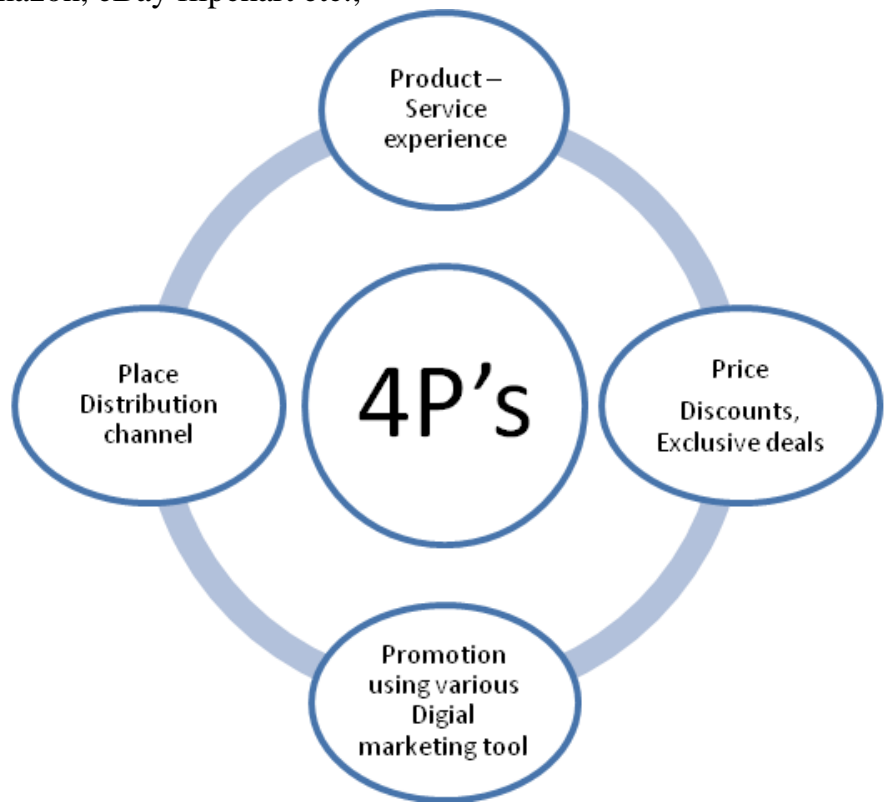

It's for promoting the business to clients as well as showcasing the business to business and clients in every one of the four blends the digital marketing can increase the value of. Business to Business (B2B): Digital promoting can be utilized for showcasing of business to different business visionaries additionally which is called business to business advertising.

B2B Digital Marketing enables makers and providers to promote their items and administrations before worldwide/national purchasers and in the present advanced world, it is done through online entries. Advanced promoting systems can bolster B2B showcasing admirably since B2B connections are once in a while around a prompt coincidental exchange. Or maybe it is tied in with building notoriety, exhibiting capacity and displaying believability.

Client to Customer (C2C): When a man discusses an organization's item and administrations with family and companions. For instance post viewing a film the client communicates is certain input to other individuals through different methods of correspondence which makes a prospect client.

Client to Business (C2B): in which purchasers (consumers) make esteem and organizations devour that esteem. For instance, when a buyer composes audits or when a customer gives a helpful thought for new item improvement then that purchaser is making an incentive for the business if the business receives the info. Excepted ideas are swarm sourcing and co-creation.

Business to Customer (B2C): Promoting the item to the client through computerized showcasing.

\section{OBJECTIVE OF THE STUDY}

Objective of the study is to show, how to create a brand image in digital marketing through customer voice.

\section{REVIEW OF LITREATURE}

The literature has been reviewed from books, websites, etc.

$>$ Stated by Philip Kotler: The different books have been alluded where we can see the advancement of showcasing, the development has been because of progress in innovation, the change has offered ascend to computerized promoting from conventional yet in addition specified.

$>$ Understanding the customer behavior and the factors effecting customer is clearly showcased in Fundamentals of Digital Marketing by Puneet Singh Bhatia. It would be absurd for any organization to 
go over the edge on advanced media. Organizations should utilize a blend of social and customary media to advance items. The development of brand showcasing made an atmosphere of responsiveness for another equation, and brands that could read the changing feelings and requirements among their purchasers in this new scene would appreciate receiving the rewards.

> Marina Johansson (2010) discusses how social networks has influenced the brand image, brand equity and brand awareness. Brand equity is generated through brand awareness. She discusses how the social media is assisting in creating the brand awareness among the customers

$>$ In Building brand loyalty Yuvraj and Indumathi (2018) has noticed that, the increased usage of personal devices has paved way to digital marketing and increased ways of communicating with the target customers when compared to traditional marketing.

$>$ "Assessing the consumer decision process in the digital marketplace" Thompson S.H, Teo, Yon Ding Yeong. "Omega The International Journal of Management Science" This paper focuses on consumer decision making process in reference to online shopping in the Singapore market. They have conducted internet survey and 1133 responses received, using structural equation model, they finding perceived risk has a negative relationship with consumers, they state in the paper, there is a positive relationship between perceived benefits of search and overall deal evaluation. The various further studies suggested by the paper, will be useful to understand the effect of digital marketing in consumer buying decision model. And the paper suggests the study for both B2C and B2B customers.

$>$ Digital Marketing Strategies that Millennial find Appealing, Motivating or Just Annoying, Dr. Katherine Taken Smith, the purpose of the study was to understand the commonly used digital media and that would affect the millennium audience. They have done analysis based on survey of 571 millennial. Which gives an outcome, millennial prefers certain forms of digital advertising, while avoiding others. Results also indicate that the digital marketing strategies that are considerably more effective than others in grabbing the attention. The study limitation is of only 571, and with changing environment, the study needs to done periodically to understand the present affect of digital marketing on consumers.

$>$ An Empirical study on effectiveness and challenges of Digital Marketing in Bangladesh, Md Sajedul Islam. International Journal of Engineering and Management Invention (IJEMI) Volume 01/Issue 01/August 2016. The study shows online marketing strategies in Bangladesh, the study shows the comparison of traditional marketing and digital marketing system. The conclusion of the study is Digital marketing has become an essential part of strategy of many companions boundaries attached, with various sophisticated electronic devises which can be used.

\section{Research Methodology:}

The research methodology that has been adopted for this article is analysis of live case study from secondary source of information.

Discussion about a live case study- Apollo Munich Insurance.

Let's analyze and understand the above concept taking a case study-"Apollo Munich Insurance" has created brand awareness among the consumers through digital way.

Apollo Munich Health Insurance Company Ltd. is a private part medical coverage organization in India. Established on 8 August 2007, it is a joint venture between the Apollo Hospitals group and Munich Health, one of the three business fragments of Munich Re; a main reinsurance organization situated in Germany

Creating Awareness: Apollo Munich started with advertisements of the company creating awareness to people. The awareness of primary regarding the company selling insurance. This created awareness among people interested to buy health insurance.

Creating Positioning: Once the company was known to the potential clients the next step was identify the direct customers, understand how each competitors is positioning their brand, comparing our position to the competitors identify the uniqueness, develop a distinct and value based positioning idea. Craft a brand position statement, a positioning statement is a one or two sentence declaration that communicates your brand's unique value to your customers in relation to your main competitors.

Customer Perception: Apollo Munich is merger of two companies' and Apollo is one of the old hospitals in India. It carries a prestigious name and brand and this is a value addition in terms of creating a positive perception for the customer. Since the company is having healthcare background customers will definitely have a comfort in buying the product. Hence the background has played a major role in creating positive perception through digital marketing.

Creating Customers: Once the need and preference, is known the awareness is created with a positive perception of product and service is sold.

Customer Loyalty: Today, an ever increasing number of individuals are getting to be noticeably acclimated with utilizing the web to discover data about items and administrations, all things considered, mark supervisors realized that making their items or brands online nearness is ending up imperatively critical too. Consequently, the act of Digital Marketing sets the bar high to have a magnificent client relationship administration set up. 
Inventive items have been showcased by Apollo Munich with big names, likewise there has dependably been persistent relationship kept up by Apollo Munich with clients through, TV includes, Face book, tweeter and so on which has made client unwaveringness. Apollo Munich Health Insurance took off \#Be insured advertisement crusade to feature the exceptional advantages of its progressive Health Wallet design, as of late propelled under another class 'WINSURE'. Wellbeing Wallet, a cutting edge medical coverage design, not just tends to the present needs of the clients by paying for their hospitalization yet additionally covers their OPD costs that are normally not secured by health care coverage arrangements. Strikingly, Health Wallet likewise guarantees reasonableness of proceeding with the arrangement in later years.

Post analysis based on this case study, we can say there are two areas the digital marketers should work on (i) awareness of digital marketing (ii) Creating a positive customer perception. Brand can be created through digital marketing following the below mentioned steps.

$>\quad$ Creating Brand

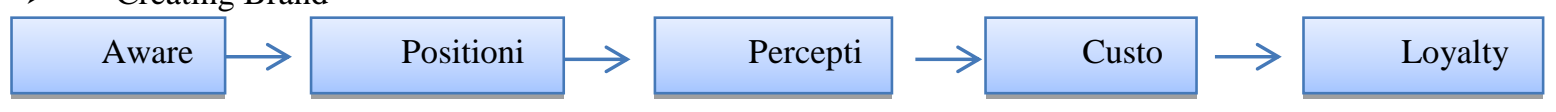

Creating Aware

ness: For whatever length of time that you're putting forth a fantastic item or administration, odds are that a great many people will be more than willing to pay a smidgen of additional cash to help your business. Making an attention to the item among prospect clients is the main phase of showcasing and in this day and age through digital marketing the same can be accomplished all the more viably. Making mindfulness and making positive client recognition through advanced advertising go in a line. The way to achieving the majority of this is to discover your intended interest group as well as characterize the particulars of your organization's offerings and guarantee those offerings (items and administrations) are in accordance with the requirements and needs of your potential clients.

Creating Positioning: Making Positioning: Is your main thing in the psyche of your objective buyer not what you do to an item or administration. Feeling has been appeared to be the principal driver of basic leadership on a buyer's way to buy. Emotional positioning examples include Coca-Cola, which exists to inspire moments of happiness and Cadbury, which exists to inspire moments of joy.

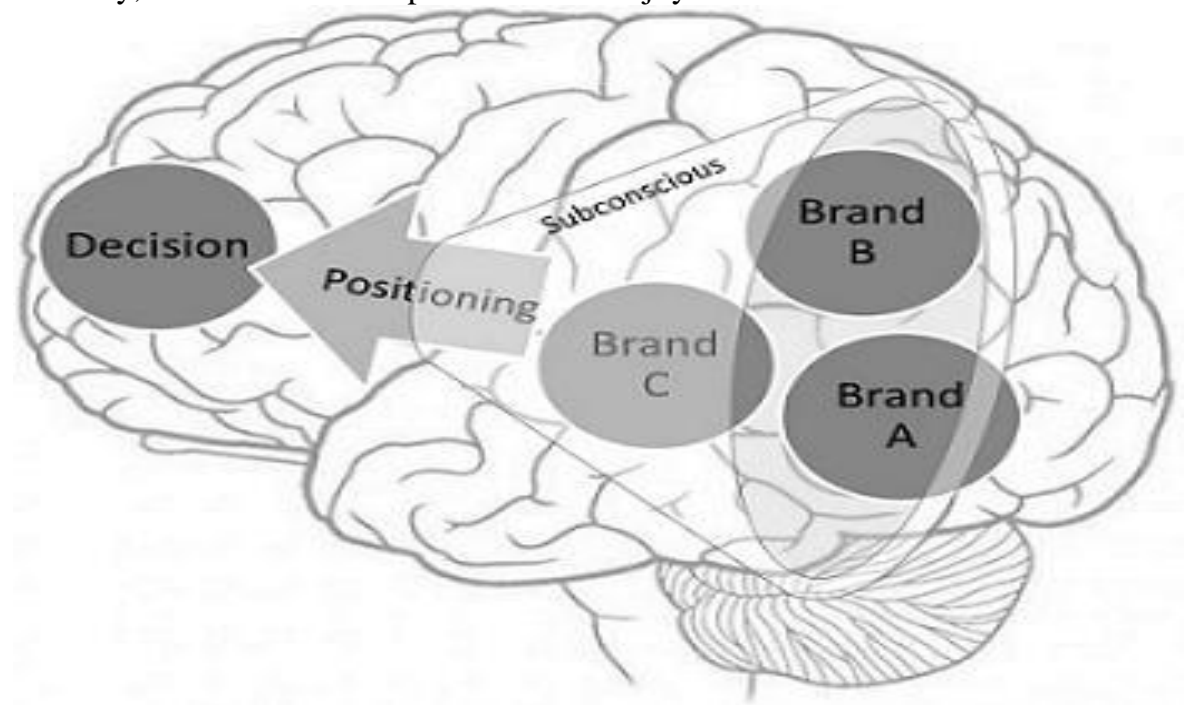

Customer Perception: Customer has a tendency of developing perception of the product or services before purchase. Perception usually varies from customer to customer, product as well as service quality. Hence, from business or marketing point of view, it is essential for them to track down the customer behavior pattern and their perception and therefore need to address with the same effectively and efficiently.

Creating Customers: Once the client knows about the item and an item position and observation has been made and subsequent stage is buy of the item consequently bringing forth client

Customer Loyalty: Next retaining the client, making reliability is the most critical advance, letting know the client what you are improving the situation, doing likewise by digital marketing, in the event that you don't say each one of those things the organization is doing the client may not know, consequently keeping up consistent contact with the client through advanced mode is extremely fundamental.

\section{CONCLUSION:}

Change is constant, innovation and new technologies should be accepted. Digital marketing acts as a catalyst to build brand through customer. Marketing team, agencies, distribution channels do not build brand customer do. 
Brand is nothing but an emotion, perception build in the customer mind. These emotions are created via visual effects through digital marketing. In today's digital world there are various modes of marketing hence creating a wider platform for the marketers to sell their product and services. Now understanding the difference and factors influence a consumer behavior in digital market, the costumer perception towards a digital shopping has given importance. Hence the marketers should be aware of the fact that a positive customer perception has been created to earn profits through digital marketing.

\section{REFERENCES}

1. David L Loudon \& Albert J. Della Bitta (2002) Consumer Behavior by (Chennai: Mc Graw Hill Education: 2002)

2. Thompson S.H, Teo, Yon Ding Yeong. (2003) "Assessing the consumer decision process in the digital marketplace" "Omega The International Journal of Management Science" October 2003Omega 31(5):349-363 DOI: 10.1016/S0305-0483(03)00055-0

3. BHAGOWATI, DARSHANA, and DEV MALYA DUTTA. "A STUDY ON LITERATURE REVIEW FOR IDENTIFYING THE FACTORS IMPACTING DIGITAL MARKETING." International Journal of Sales \& Marketing Management Research and Development (IJSMMRD) 8.3, Aug 2018, 1-8

4. Dr. Katherine Taken Smith,(2011) "Digital Marketing Strategies that Millennial find Appealing, Motivating or Just Annoying," " Journal of Strategic Marketing” 19(6) DOI: 10.2139/ssrn.1692443

5. MAFAZI, MUHAMMAD ATRAS. "CAPITAL BUDGETING ANALYSIS IN DIGITAL MARKETING ACTIVITIES AT YES CAKE \& BAKERY." International Journal of Business Management \& Research (IJBMR) 8.6, Dec 2018, 1-8

6. Md Sajedul Islam. (2016) "An Empirical study on effectiveness and challenges of Digital Marketing in Bangladesh" International Journal of Engineering and Management Invention (IJEMI) Volume 01/Issue 01/August 2016.

7. SHUKLA, NEHA. "SOCIAL MEDIA \& ITS INFLUENCE ON CUSTOMER RELATIONSHIP IN INDIAN RETAIL SCENARIO." International Journal of Sales \& Marketing Management Research and Development (IJSMMRD) 7.4 (2017): 27-34.

8. Puneet Singh Bhatia (2017) Fundamentals of Digital Marketing (Chennai: Pearson 2017)

9. Dr. S. YUVARAJ, R. INDUMATHI(2018)" INFLUENCE OF DIGITAL MARKETING ON BRAND BUILDING" International Journal of Mechanical Engineering and Technology (IJMET) Volume 9, Issue 7, July 2018, pp. 235-243,

10. Sankaran, V. Siva, and N. Kannan. "Increasing Brand Reputation through Viral Marketing." International Journal of Sales \& Marketing Management Research and Development (IJSMMRD) 6.1 (2016): 1-8.

11. Nazimsha, S., and M. Rajeswari. "COMPARING DIGITAL MARKETING WITH TRADITIONAL MARKETING AND CONSUMER PREFERENCE, OVER WHICH MEDIUM BY TAKING CONCEPT OF ADS." International Journal of Sales \& Marketing Management (IJSMM) 7.1, Dec-Jan 2017; $1-12$

12. Websites: Regarding health issues in rural India www.wikipedia. 